STATE OF ILLINOIS

DEPARTMENT OF REGISTRATION AND EDUCATION

DIVISION OF THE

NATURAL HISTORY SURVEY

STEPHEN A. FORBES, Chief

\begin{tabular}{lll}
\hline Vol. XIII. & BULLETIN & Article XII.
\end{tabular}

\title{
NEW SPECIES AND VARIETIES OF PHYLLOPHAGA
}

BY

JOHN J. DAVIS

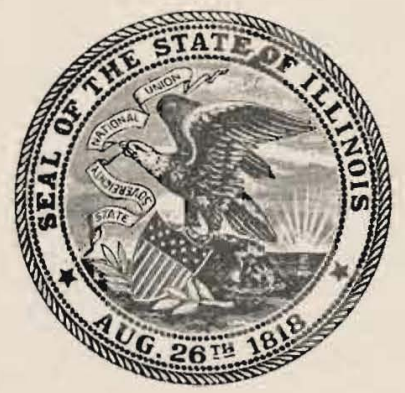

PRINTED BY AUTHORITY OF THE STATE OF ILLINOIS

URBANA, ILLINOIS

August, 1920 


\section{ERRATA}

Page 97, line 17, for first larval read pupal.

Page 112, in legend, for jonessi read jonesii.

Page 114, in legend', for or read of.

Page 125, line 4, for Bonosa read Bonasa.

Page 131, in legend, for hirundinaceus read hirudinaceus.

Page 138, last line, for coccoon read cocoon.

Plate XII, explanation page, next to last line, for acrivora read aerivora.

Plate XIII, explanation page, next to last line, for White-grubs read White-grub.

Page 293, Figure $5 a$ was reversed in printing, and the two items of the legend should change places.

Page 515, second table, for Pelocoris femorata read Pelocoris femoratus. 
Article XII.-New Species and Varieties of Phyllophaga. By John J. Davis, Riverton, New Jersey.

Among the many collections of May-beetles received from entomologists throughout the country have been found several apparently new species and varieties. Requests from the collectors for names which they could use in writings prompt the author to present the following descriptions.

I wish to acknowledge my indebtedness to Dr. Henry Fox for the drawings of the genitalia of perlonga, mississippiensis, pearliae, foxii, impar, and comosa, and to Mr. R. E. Snodgrass for the detail drawings of the anal segment of the larvae of perlonga and mississippiensis.

\section{Phyllopitaga perlonga, n. sp.}

This large characteristic species is typical of the fusca group and apparently is nearest $P$. drakii (grandis Sm.) and P. karlsioci Linell, but is distinct from both species. It has been designated in the writer's determinations as new species "a".

The species is rather large, measuring 22 to $25 \mathrm{~mm}$., with elongate body, rufocastaneous to almost piceous, thorax shining, elytra dull to moderately shining. Clypeus slightly emarginate, the border moderately reflexed, surface moderately but not closely punctate, front similarly punctate. Thorax widest at base, sides nearly parallel posteriorly, conspicuously arcuate anteriorly, margin entire, disc with feeble not closely placed punctures and with an inconspicuous smooth median line. Elytra with punctures similar to those of thorax but slightly rugulose at middle. costae inconspicuous. Metasternum rather densely hairy. Abdomen shining, sparsely and finely punctate. Claws curved, the tooth median, always noticeably stronger in the female.

Male.-Antenna 10-segmented, the club about as long as the stem, abdomen broadly flattened, the penultimate segment with a short, strongly arcuate ridge bordered with moderately long fine hairs, projecting in the manner of a ledge but not reaching to the posterior edge of the segment, the last segment rather strongly impressed, forming a cupshaped depression. Fixed spur of hind tibiae approximately two thirds the length of the outer spur. The claspers are dissimilar and quite characteristic (P1. XL, Fig. 1-4).

Female.-Antenna with club short, about half the length of the stem. Penultimate segment transversely impressed near the posterior ventral margin. The pubic process similar to that of $P$. drakii ( $\mathrm{Pl}$. XL, Fig. 5). 
Grub.-The larva is characteristic of the genus. Figure 1, showing the arrangement of the two rows of spines and surrounding hairs and spines on the under side of the last abdominal segment, suffices for description.

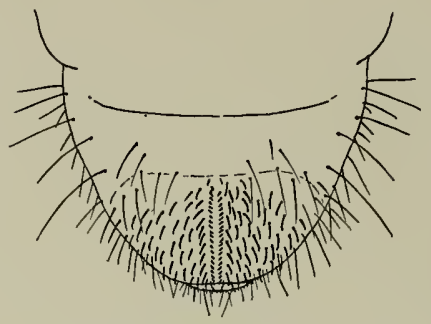

FIG. 1. Under side of anal segment of larva of Phyllophaga perlonga, n. sp.

Habitat.-We have this species represented by five or six hundred specimens collected by Prof. R. W. Harned and his assistants and students, at Agricultural College, Miss., March 19 to June 21, with isolated records for July and August, the period of greatest abundance being March and April. We have seen specimens from Greenville, Shubuta, Starkville, and West King Junction, Miss., and from Gum Springs, Clark Co., Ark., all of which were also collected by Professor Harned and his assistants. This species was collected at Clarksville, Tenn., from April 16 to May 25 in 1917 by Dr. Henry Fox, and from April 2 to May 8 in 1918 by Fox and Max Kisliuk, and at Knoxville, Tenn., May 8 to 10, 1916, by G. G. Ainslie and C. C. Hill. In most cases the beetles were collected at lights, but a few, collected at Agricultural College, were taken on pecan, elm, and hickory, and several at Clarksville were found on elm and honey locust.

Phyllophaga fraterna Harr., var. mississippiensis, n. var.

The above variety belongs to the fusca group according to Horn's synopsis. It has been designated in the writer's determinations as new species "b".

About the size of the largest specimens of $P$. fraterna, varying in length from 18 to $21 \mathrm{~mm}$. and averaging $20 \mathrm{~mm}$., ru focastaneous to piceous, the darker forms predominating, only moderately robust, shining. Clypeus acutely, moderately deeply emarginate, border moderately reflexed, densely punctate, front similarly punctate. Thorax apparently widest at middle, obtusely angulate, margin indistinctly crenate, the punctures only moderately dense and sometimes slightly irregularly placed. Elytra with incon- 
spicuous punctures, somewhat rugulose in middle. submarginal costae indistinctly visible on distal half, distal costae moderately distinct. Pygidium not closely punctate, the punctures not clearly defined. Metasternum not densely hairy, finely and rather densely punctate Claws curved and with a strong median tooth in both sexes.

Male.-Antennal club nearly as long as the stem. Abdomen narrowly flattened at middle, penultimate segment with a transverse rugulose area which is scarcely elevated. Last segment concave on median ventrum, smooth except for a few papilla-like elevations near posterior side of concavity. Fixed spur of the hind tibia rather short and broad, being about one half the length of the outer spur. Genitalia large, the left clasper being especially large (P1. XLI. Fig. 6-9). They closely resenble those of $P$. fratcria, even in the tendency to a notch in the posterior margin of the left clasper.

- This variety differs from the typical fraterna especially in being larger, and in having relatively larger genitalia and larger antennal club.

Female.-Antennal club very small, as short or shorter than the funiculus. Penultinate with a transverse impression on the under side near the posterior border. The genitalia are strikingly like those of typical fraterna, and are sufficiently illustrated in Figures 10 and 11, Plate XII.

Grub.-The ventral surface of the last abdominal segment is shown in Figure 2. We have compared this grub with that of $P$. fratcrna, and find them apparently separable: The two rows of spines on the under side of the last abdominal segment are similar but the surrounding hairs



Fig. 2. Under side of anal segment of larva of P. fraterna, var. mississippiensis.

and spines show an apparently constant difference, those of typical fraterna being more sparsely placed, and consequently there are fewer spines. and the anterior spines and hairs being less robust. 
Habitat.-Several hundred specimens of this variety have been examined, all of which were collected in Mississippi by Prof. R. W. Harned or his assistants excepting the collections at Greenwood, which were made by Mr. J. M. Langston. The collection localities include Agricultural College, Kiln, Greenwood, Caesar, Ellisville, Forkville, and Starkville, Miss. ; the food plants of the beetle include poplar, elm, hickory, black oak, plum, apple, and pecan--the latter apparently preferred; and the dates of collection range from March 19 to June 4, April being the period of greatest abundance.

\section{Phyllophaga pearliae, n. $\mathrm{sp}$.}

This species belongs to the fusca group according to Horn's synopsis, but the genitalia are quite distinct from all recorded species. It has been designated in the writer's determinations as new species "c". .

The specimens before me are moderately shining, quite variable in color, ranging from reddish brown to almost piceous, the lighter colored specimens with the head and thorax darker. Clypeus densely punctate, narrowly reflexed, moderately deeply and obtusely emarginate, front similarly punctate. Thorax moderately punctate, the punctures fairly uniform and distinct, noticeably narrowest at front, very slightly wider at base than at middle, margin plainly crenate but not conspicuously so. Elytra with punctures finer and more closely placed than on thorax, sutural coxae well marked, the others wanting or scarcely visible. Pygidium with punctures indistinct. Metasternum with hair moderately sparse and short. Claws arcuate, strongly and equally toothed at middle in both sexes. Length, 18 to $20 \mathrm{~mm}$.

Male.-Antenna 10-segmented, the antennal club as long as stem. Abdomen flattened at middle, the penultimate segment depressed along the posterior border and with a slight but noticeable transverse ridge in front of the depression which is more abrupt at sides, the last segment concave in middle. Fixed spur of hind tibia short and stout, being half, or less, the length of outer spur. The genitalia distinctive, claspers dissinilar, the left being large, the right smaller and with a characteristic hook, as illusrated. (P1. XLII, Fig. 12-15.)

Female.-Antennal club about half the length of the stem. Penultimate ventral segment with a linear transverse impression near the posterior margin. The genitalia characteristic, and well illustrated in Figures 16 and $1 \%$, Plate XLII.

This is a typical bottom-land species and was fairly common in the collections of Dr. Henry Fox in 1917 and of Fox and Kisliuk in 1918 in the Red River bottoms at Clarksville, Tenn. They collected it from April 29 to June 11 on elm (? American), winged elm, buttonwood, willow, and honey locust, by far the greater number being taken on honey locust. Mr. D. G. Tower collected a specimen of this species May 24, 1915, under a $\log$ in a woods at Princeton, Ind., and the writer found a 
number of individuals on walnut and honey locust May 21, 1913, near Louisville, $\mathrm{Ky}$., in an area not far back from and little elevated above the Ohio River.

The writer dedicates this species to his wife in testimony to her philosophical consideration of the continuous nightly collecting trips necessary to a study of the Phyllophagae, and of the equally necessary 2 a. m. luncheons which were invariably awaiting the collector's return.

\section{Phyllophaga forsteri Burm.}

The species which the writer has designated in his determinations as new species " $\mathrm{d}$ ", is apparently $P$. forsteri ( $=P$ nova), a species quite variable. All which have been determined as n. sp. " $d$ " were collected in Florida.

\section{Phyllophaga forbesi Glasgow}

The species referred to by the writer in his early determinations as new species " $e$ " has since been described by Mr. R. D. Glasgow as P. forbesi.*

\section{Phyllophaga SOROR n. sp.}

This small species, which belongs to the quercus group and runs to the species affabilis in Horn's synopsis, is distinct from that species but resembles clypeata in genital characters. It differs from the latter species in the emarginate clypeus, and there is a slight but constant difference in the genitalia of both sexes. This species has been designated in the writer's determinations as new species " $f$ ".

Body oblong, rufotestaceous or darker, the thorax usually more of a reddish brown, with the head darker, surface moderately shining. Clypeus broadly emarginate, margin moderately reflexed, punctures moderately close, front very slightly more punctate. Thorax moderately densely punctate, sides regularly arcuate, not angular, widest at middle and somewhat narrowed at front, less so at base, margin entire and with sparsely placed ciliae. Elytra with moderately dense punctures, the sutural and discal costae moderately prominent, the submarginal ones indistinct or absent. Pygidium with fine, sparsely placed punctures. Claws with tooth of moderate size and basal in male; larger and median in female. Metasternum sparsely hairy. Length, 13 to $15 \mathrm{~mm}$.

Malc.-Antenna 9-segmented, the club noticeably shorter than the stem. Abdomen flattened at middle, the last segment with a transverse elevated ridge near anterior margin, broken in the middle with a concavity. Inner spur of hind tibia free and about one half or less the

* Bull. Ill. State Lab. Nat. Hist.. Vol, XI (Art. V), p. 378. 
length of the outer spur. The genitalia with. claspers symmetrical and simple (Fig. $3-5$ ).

Female.-Antennal club very small and shorter than the funiculus. The pubic process is a flat broad plate and decply notched at the tip (Fig. 6).

Habitat.-Collected at Raleigh, N. C., July, 1916, by R. IV. Leiby, and at Columbia, S. C., June 26, 1914, by P. Luginbill and A. H. Beyer.

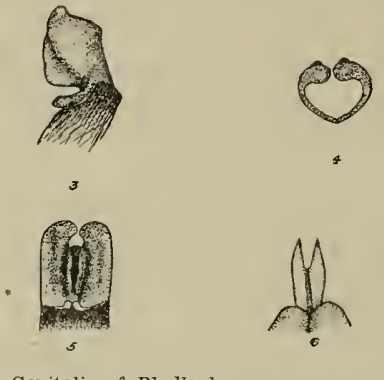

Genitalia of Phyllophaga soror, n. sp.

Fug. 3, right clasper; FIG. 4, dorsal view of same; FIG. 5 , front view of male genitalia; Fig. 6 , pubic process of female.

\section{Phyllophaga foxit, n. sp.}

This species belongs to the fusca group. In many respects it resembles fraterna and in certain characters it approaches infidelis, but is apparently quite distinct. In the writer's determinations it has been designated as new species " $g$ ".

Body rufocastaneous to piceous, in the lighter specimens the head darker, sometimes both head and thorax darker. Clypeus moderately deeply emarginate, margin moderately reflexed, coarsely and densely punctate, front slightly less densely punctate. Thorax narrowest at front, the width at middle and at base subequal, sides somewhat angulate, margin indistinctly crenate, sparsely ciliate, punctures moderately sparse and slightly irregular in distribution. Elytra with punctures finer but more densely placed than on thorax, sutural costae distinct, subnarginal ones evident but indistinct, especially the distal half. Pygidium with a moderate number of indistinct punctures. Hairs on metasternum moderately sparse. Claws arcuate, with strong median tooth in both sexes. Length, 16.5 to $18 \mathrm{~mm}$.

Male.-Antenna 10-segmented, the club nearly as long as the stem. Abdomen flattened at middle, penultimate segment granulate in middle 
with an oblique ridge or tuberosity on either side, last segment with a transverse oval depression. Inner spur of hind tibia short and stout, the outer more slender and fully twice as long. Genitalia resemble those of infidelis in many respects but are also constantly different (P1. XLIII, Fig. 18-21).

Femalc.-Antennal club about as long as the funiculus. Last ventral segment broadly emarginate. The pubic process is quite different from that illustrated by Smith for $P$. infidelis, and resembles the fraterna-rugosa type. The genitalia are sufficientiy illustrated in Figures 22 and 23 , Plate XLIII.

Habitat.- This species has been collected at Tappahannock, Va., by Fox, and at Columbia, S. C., by Luginbill and Beyer. The Virginia collections were made April 26, 1915, and April $\gamma$ to May 2, 1916, and were taken on the following plants: blackberry (Rubus nigrobaccus), blueberry (Vaccinium sp.), wild rose (Rosa sp.), persimmon (Diospyros airginiana). red oak (Quercus rubrum), Spanish oak ( $Q$. falcata), and locust (Robinia hispida). The South Carolina collections were made April 1; to May 29. 1916, and were taken on persimmon, elder bush, black gum, hackberry, birch, and sour gum.

It is with nuch pleasure that the writer names this species in honor of Dr. Henry Fox. Dr. Fox has made collections in Indiana, Virginia, Tennessee, and Georgia which are invaluable in our studies of the distribution, food plants, and ecological relations of the Phyllophagae.

\section{Phyllophaga impar, 12. Sp.}

This very interesting species, occurring, according to our records. only in the Carolinas, apparently belongs to the ephilida group of Horn's synopsis, but is quite distinct from all described species belonging to that group. It has been designated in the writers determinations as new species "h".

Body oblong. slightly broadest behind. reddish brown or darker, the surface sometimes shining but usually more or less pruinose, and in one specimen the surface has a dull smoky appearance such as sometimes occurs in $P$. prumunculina. Clypeus feebly emarginate, moderately reflexed, slining, with punctures varying from comparatively sparse to moderately closely placed, front similarly punctate. Thorax narrow at front, being little more than half the greatest width, width at middle very little if any less than basal width, punctures moderately sparse. Elytra more coarsely and apparently more cloșely punctate than thorax, costae, excepting the sutural, indistinct or absent. Scutellum smooth or with a few very indistinct punctures. Pygidium with a moderate number of fine punctures. Metasternum only moderately hairy. Claws strongly arcuate and with a moderately large median tooth. Length, $13 \mathrm{~mm}$.

Male.-Antenna 10-segmented, the club as long as the stem. Abdomen almost imperceptibly flattened on median ventrum, the penultimate 
segment without characteristic sculpture. Inner spur on hind tibia short, being less than half the length of the outer spur, which is long and slender. The genitalia are remarkable because of the dissimilarity of the claspers. The right clasper is slender and gives an impression of having been aborted; the left clasper is strongly arcuate. The illustrations (PI. XLIV, Fig. 24-2\%) show the characteristics of the genitalia.

Fomale.-The female is unknown.

Habitat.-We have this species from only two localities; from Southern Pines, N. C., collected by A. H. Manee, and one specimen, from Columbia, S. C., collected by P. Luginbill and A. H. Beyer in 1915.

\section{Phyllophaga parvidens Lec., var. hysteropyga, n. var.}

This variety has the general appearance of $P$. crenulata but is nearest related to $P$. rubiginosa and typical $P$. parvidens, to which species it runs in Horn's synopsis. The male genitalia are identical with those of $P$. parvidens, and there appears to be no constant difference excepting size. This variety is much smaller than any typical parvidens which I have seen, being about two thirds the length of that species and not more than half the, bulk. Variety hysteropyga has many characters in common with $P$. pygidialis, but a comparison with the type of that species shows it to be quite distinct. In the writer's determinations this variety is designated as new species " $\mathrm{j}$ ".

Body oblong, very little widest posteriorly, brown, head darker, thorax feebly shining, elytra with a slight pruinosity, head and thorax with a moderate number of more or less erect yellowish hairs, the elytra
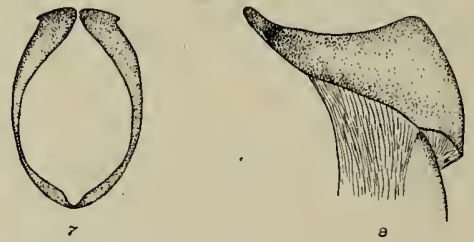

Genitalia of Phyllophaga parvidens, var. hysteropyga. FIG. 7, dorsal view; Frg. 8, right clasper.

with short fine recumbent hair with a few longer erect hairs near anterior end. Clypeus emarginate but not deeply so, the border narrowly reflexed, surface moderately and rather finely punctate, front slightly more densely punctate. Thorax noticeably narrowest at front, the width at middle and base subequal, margin crenate and with moderately long ciliae, surface rather sparsely and finely punctate. Elytra densely punctate, 
somewhat rugulose, especially on the median dorsum, recumbent and erect hairs as already described. Pygidiun finely and uniformly punctate and set with moderately short recumbent hairs. Metasternum with long hairs rather densely placed. Abdomen slightly pruinose with uniformly short fine recumbent hairs. Claws curved at apex and with a moderatesized median tooth. Length, 15 to $16 \mathrm{~mm}$.

Male.-Antenna 10-segmented, the club as long as the stem. The genitalia are simple but characteristic, as shown in Figures 7 and 8 . Penultimate ventral segment slightly flattened at middle and granulate.

Female.-The female is unknown to the writer.

Habitat.-This species is represented by four males collected by J. D. Mitchell at light, Victoria, Texas, April 6-June 26 (exact date unknown), and we have seen one male collected by W. S. Blatchley at Sanford, Fla., March 25, 1911.

Phyllophaga hirticula Ḱnoch, var. comosa, n. var.

This variety closely resembles typical $P$. hirticula, but may be distinguished by the absence of the rows of hairs on the elytra and the shortness or sparseness of the hairs on the thorax. This character seems to be constant, judging from the long series before me and the statement of the collectors, McColloch and Hayes, who report having collected numbers of this variety without finding any with the rows of hairs on the elytra. The genitalia resemble those of typical hirticula, and while there seems to be a constant slight difference in the male genitalia, the difference is so slight as to make it difficult to separate the variety on this alone. The genitalia of variety comosa are thicker and more robust than are the genitalia of hirticula.

Similar in shape and color to typical $P$. hirticula, being fuscoferruginous to very dark brown, moderately shining, without hairs on elytra except an occasional short one, and only a few on the head and thorax. Clypeus rather deeply emarginate, the margin narrowly reflexed, surface coarsely and densely punctate, front similarly punctate. Thorax slightly narrower at base than at middle, margin finely serrate posteriorly, coarsely so anteriorly, and with short ciliae, surface moderately closely punctate on sides and less so on disc, the punctures more or less irregularly placed, a rather distinct channel along basal margin from the hind angles to near the middle. Elytra with smaller and moderately closely placed punctures, somewhat rugulose at center," no rows of hairs, only an occasional short hair, and margin not fimbriate, sutural costae distinct, submarginal ones indistinct or absent. Pygidium with punctures moderately sparse and not distinct, wider than long, the apex broadly rounded. Metasternum with fine derse punctures and densely clothed with moderately long hairs. Claws arcuate, with a strong median tooth, alike in both sexes. Length, 16.5 to $18.5 \mathrm{~mm}$. 
Malc.-Antenna 10-segmented, the club not quite as long as the stem. Abdomen flattened at middle, the posterior margin depressed, giving the general appearance of a transverse ridge across the anterior half or two thirds of the segment, which is more abrupt at sides. Last segment with a transverse oval depression on under side. Inner spur of hind tibia moderately short and about half the length of the outer. The genitalia are shown in Figures 28-31, Plate XLV.

Female.-Antennal club short, being about as long as the funiculus. The genitalia are illustrated in Figures 32 and 33, Plate XLV.

\section{Phyllophaga postrema Horn}

The writer has had no opportunity to examine the types of $P$. postrema or $P$. quadrata Sm., but a study of our collections indicates that they are identical. The former is known only by the male and the latter by the female.

Types of all the species and varieties described in this paper are deposited in the collections of the Illinois Natural History Survey; paratypes of the same, in the United States National Museum and in the writer's collection; and paratypes of perlonga, mississippicnsis, pearliac, soror, foxii, and comosa have been deposited in the collections of the American Museum of Natural History and of the Philadelphia Academy of Sciences.

Plate XL

Phyllophaga perlonga, n. sp.

FiG. 1. Left clasper.

Fig. 2. Right clasper.

Fig. 3. Male genitalia, rear view.
FIG. 4. Male genitalia, dorsal view.

FIG. 5. Female genitalia.

(See also text figure, p. 330.) 


\section{Plate XL}

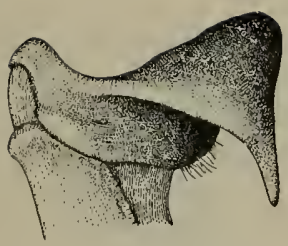

1



3



\section{Plate XLI}

Phyllophaga fraterna Harr., var.' mississippiensis, n. var.

Frg. 6. Left clasper

FIG. 7. Right clasper.

Fra. 8. Male genitalia, rear view.
Fig. 9. Male genitalia, dorsal view. Frg. 10. Female genitalia, dorsal view Fig. 11. Female genitalia, side view.

(See also text figure, p. 331.) 


\section{Plate XLI}
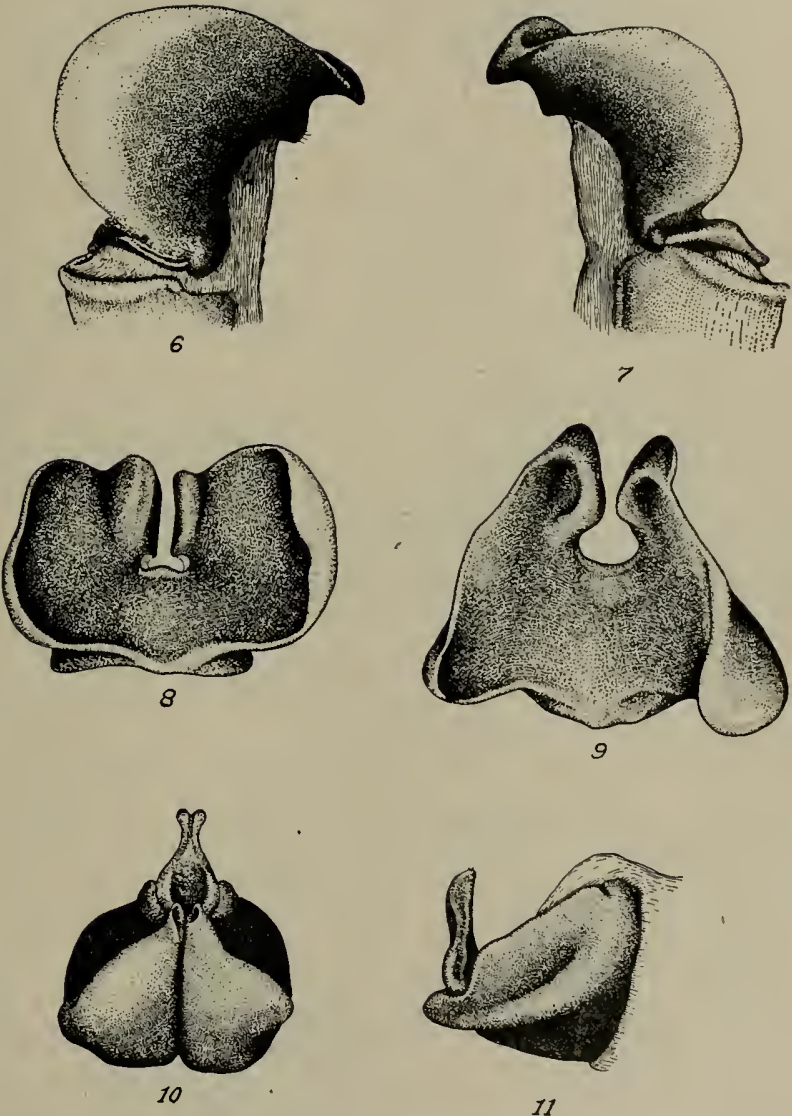
Plate XLII

Phyllophaga pearliae, n. sp.

Fig. 12. Left clasper.

Fig. 13. Right clasper.

Fit. 14. Male genitalia, rear view.
Fig. 15. Male genitalia, dorsal view. Fig. 16. Female genitalia, dorsal view. Fig. 17. Female genitalia, side view. 


\section{Plate XliI}
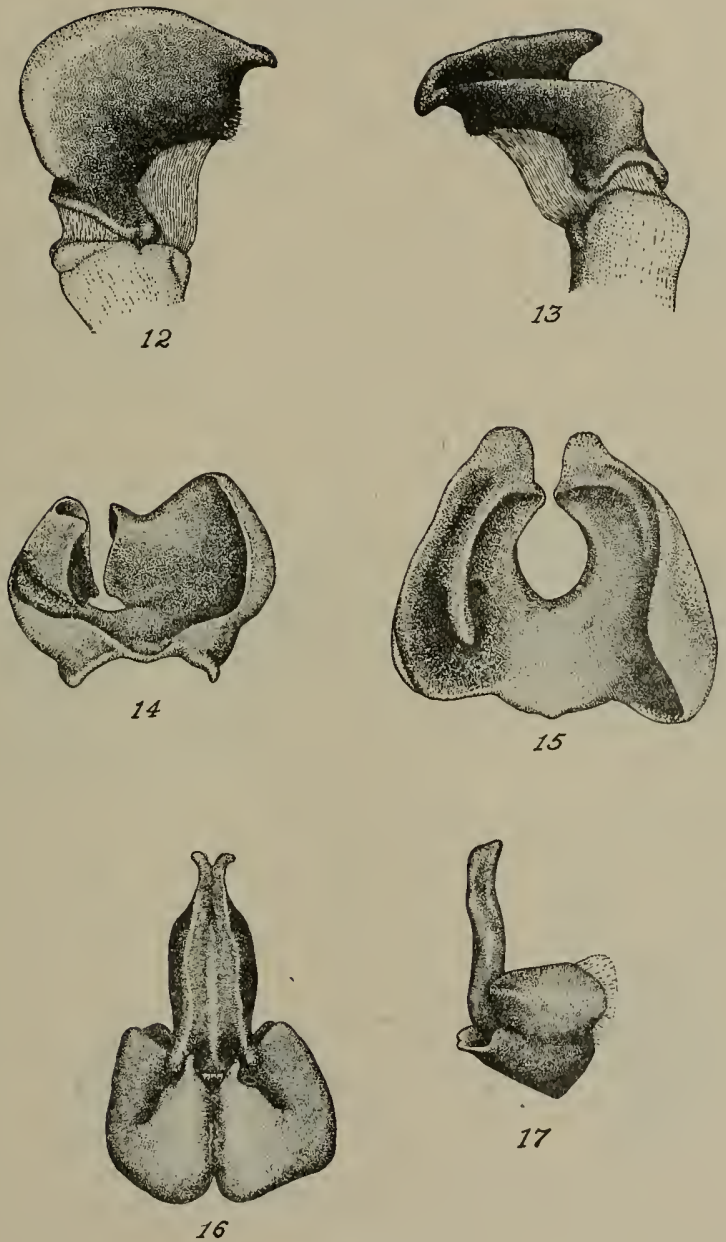


\section{Plate XLIII}

\section{Phyllophaga foxii, n. sp.}

FTG. 18. Left clasper.

Fig. 19. Right clasper.

Fig. 20. Male genitalia, rear view.
FIg. 21. Male genitalia, dorsal view.

FIG. 22. Female genitalia, dorsal view. FIg. 23. Female genitalia, side view. 
Plate XliII
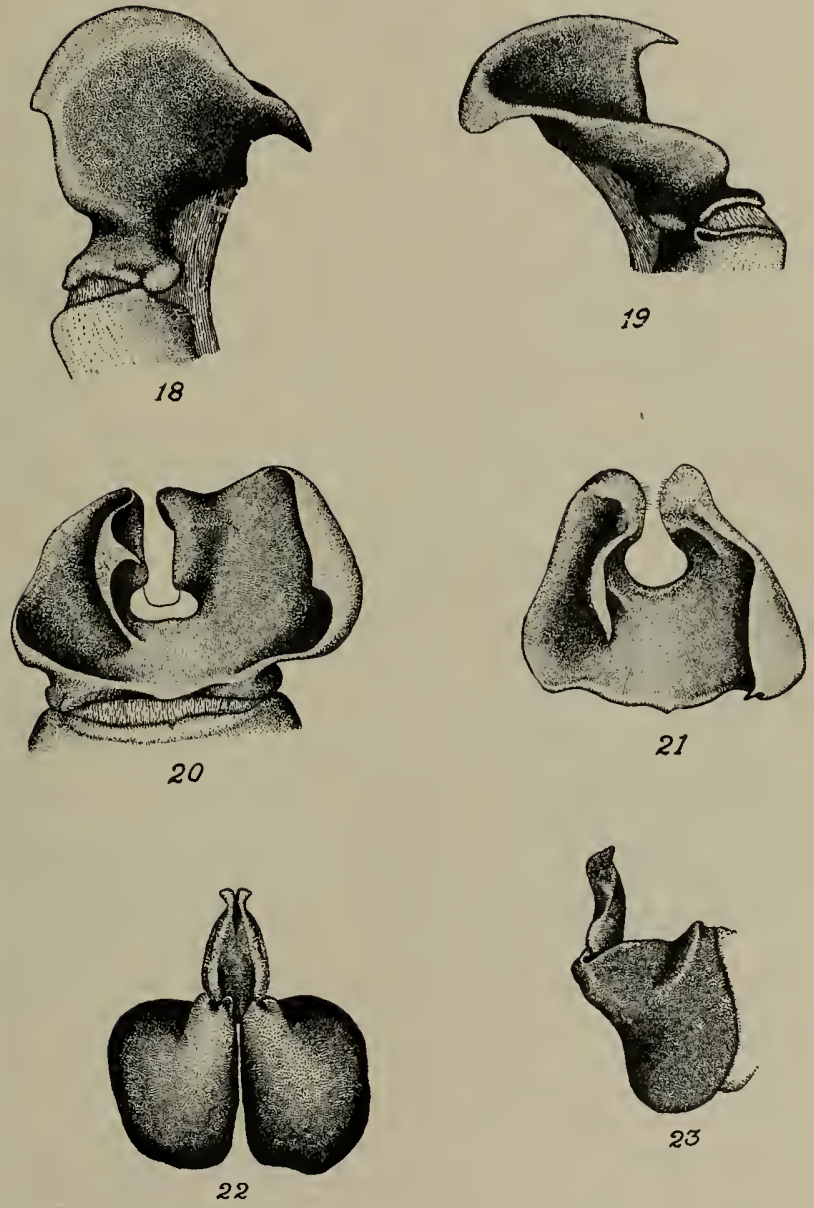
Plate XLIV

Phyllophaga impar, n. sp.

FIG. 24. Left casper.

Fig. 25. Right clasper.
Fra. 26. Male genitalia, rear view.

FIg. 27. Male genitalia, dorsal view. 


\section{Plate Xliv}


\section{4}


26 


\section{Plate XLV}

Phyllophaga hirticula Knoch, var. comosa, n. var.

FIG. 28. Left clasper.

FIG. 29. Right clasper.

FIG. 30. Nale genitalia, rear view.
Fig. 31. Male genitalia, dorsal view.

FIG. 32. Female genitalia, dorsal view. FIg. 33. Female genitalia, side view. 
Plate XlV
